\title{
THE LOCAL WISDOM PRESERVATION THROUGH AKSARA LONTARAK IN THE LEARNING MATERIAL OF MAKASSARESE LANGUAGE IN ELEMENTARY SCHOOL OF MAKASSAR CITY ${ }^{1}$
}

\author{
Sitti Rabiah $^{2}$ \\ Faculty of Letter \\ Universitas Muslim Indonesia
}

\begin{abstract}
Indonesia nation has 742 regional languages, each representing one cultural system. However by this time 30 percent of the regional languages have been lost. It can be used as an indication of 30 percent regional culture that shape the national culture have been lost too. From the 742 regional languages in Indonesia, only 13 language speakers over one million people. Makassarese language is one of 13 language speakers over one million people more precisely 2.467.000 inhabitants speakers of 7.520.204 inhabitants in South Sulawesi. In the context of the Makassarese language, local wisdom can be interpreted as positive values of Makassar tribe or more broad in South Sulawesi society. Preservation efforts of local wisdom in the Makassarese language can be done by preserving aksara lontarak which is the bridge to elaborate the values of local wisdom in the past. Furthermore, this study aimed to introduce the aksara lontarak through Makassarese language learning material in elementary school. This study refers to the steps of Research and Development from the Borg and Gall, and collaborated with the research phase of Brown to produce a learning material (textbook) of Makassarese language.
\end{abstract}

Keywords: Local Wisdom, Aksara Lontarak, Learning Material, Makassarese Language, Elementary School

\begin{abstract}
Abstrak
Bangsa Indonesia memiliki 742 bahasa daerah yang masing-masing mewakili satu sistem budaya. Namun, saat ini 30\% dari bahasa daerah tersebut telah hilang. Hal ini dapat dijadikan indikasi hilangnya $30 \%$ kebudayaan daerah yang ikut membentuk kebudayaan nasional. Dari 742 bahasa daerah di Indonesia, hanya 13 bahasa yang penuturnya di atas satu juta orang. Bahasa Makassar merupakan 1 dari 13 bahasa yang penuturnya di atas satu juta orang lebih tepatnya 2.467.000 jiwa penutur dari 7.520.204 jiwa penduduk di Sulawesi Selatan. Dalam konteks bahasa Makassar, kearifan lokal dapat dimaknai sebagai nilai-nilai positif suku Makassar atau lebih luasnya masyarakat Sulawesi Selatan. Upaya pelestarian kearifan lokal dalam bahasa Makassar dapat dilakukan dengan melestarikan aksara lontarak yang merupakan jembatan untuk menggali kembali nilai-nilai kearifan lokal di masa lampau. Lebih lanjut penelitian ini ditujukan untuk mengenalkan aksara lontarak melalui bahan ajar bahasa Makassar di sekolah dasar. Penelitian ini mengacu pada langkah-langkah-langkah penelitian dan pengembangan (Research and Development) dari Borg dan Gall, serta dikolaborasikan dengan fase penelitian dari Brown hingga menghasilkan buku ajar bahasa Makassar.
\end{abstract}

Kata Kunci: Kearifan Lokal, Aksara Lontarak, Bahan Ajar, Bahasa Makassar, Sekolah Dasar

\footnotetext{
${ }^{1}$ Presented in $4^{\text {th }}$ International Seminar on Languages and Arts organized by Fakultas Bahasa dan Seni Universitas Negeri Padang on October, 23-24 2015 in Padang, Indonesia.

2 (iD https:// orcid.org/ 0000-0002-1690-0025. Corresponding author: sitti.rabiah@umi.ac.id / sittirabiah25@gmail.com
} 


\section{INTRODUCTION}

Indonesian nation has 742 regional languages. Each of these regional languages represent a cultural system. However by this time 30 percent of the regional languages have been lost. It can be used as an indication of 30 percent regional culture that shape the national culture have been lost too. (Alwi and Sugono, 2003:45) From the 742 regional languages in Indonesia, only 13 language speakers over one million people. From 729 regional languages with speakers less than one million people, approximately 169 from 729 regional languages threatened with extinction because the speakers are less than 500 people. (Yurnaldi: 2009) Makassarese language is 1 of 13 language speakers over one million people more precisely 2.467 .000 inhabitants speakers of 7.520.204 inhabitants in South Sulawesi.

Meanwhile, the regional language is one of the national culture element that is protected by the state and warranted by law. In his position as regional language, regional language serves as: (1) the symbol of the pride of the region, (2) the interface in the family and local communities, (3) a means of supporting regional and Indonesian cultures and (4) supporting regional and Indonesian literature. In conjunction with the function of Indonesian language, the regional language has the function: (1) supporting Indonesian language, (2) the introductory language in the primary schools in certain areas to facilitate the teaching of Indonesian language or other subjects, and (3) the source to enrich Indonesian language. (Alwi dan Sugono, 2003:55)

In South Sulawesi, there are several regional languages such as Buginese language, Makassarese language, Torajanese language, and Duri language. These languages are still maintained, nurtured, developed, and used as a communication tool by the communities. One of the concerns for the local government towards the development of regional language is the inclusion of regional languages as local content (muatan lokal) subjects at school. Makassarese languages taught at elementary school and junior high school. The position of regional language subjects both in elementary and junior high schools included under the local content subjects, so that these subjects can be replaced with other subjects.

Although the regional language may at any time be replaced by other subjects, but there are some things that can be considered as urgency of learning the regional language. In terms of learning development, regional languages aimed at improving the quality of learning regional languages so that the speakers have: (1) a good knowledge of regional language and literature, (2) regional language skill, and (3) a positive attitude towards the regional language, literature, and culture. However, the purpose of language learning in the South Sulawesi area still can not achieve the expected goals. It is caused by several factors, including: the lack of regional language curriculum standards and the unavailability of learning material that relevant with the curriculum.

From the side of the teaching of the regional language, Halim identifies three main functions, namely: (1) communication tool, (2) educational tool and (3) cultural tool. (Halim, 1985:184) To develop its function as a communication tool, the lesson is 
directed so that students can use the language in a proper area for the purposes to interact within the family and society. Functions as educational tool, teaching is directed so that students can acquire the regional culture values for the purpose to form nation personality and identity; while the cultural function directed to excavate and embed the regional culture values as the effort to build the student personality and identity.

Based on the explanation above, it can be concluded that the regional language, including the Makassarese language have the strategic bargaining position to be developed in the learning process, because it has advantages from the side of learning development and side of teaching development. Further in the learning process with Makassarese language learning material that use aksara lontarak, there is an effort to do the preservation towards Makassar tribe local wisdom. This paper will examine the effort to preserve local wisdom through aksara lontarak in Makassarese language learning material in elementary school of Makassar city.

\section{RELEVANT THEORETICAL REVIEWS}

This section will discuss more about the process to develop learning material of Makassarese language with the effort to preserve the local wisdom through aksara lontarak.

\section{The Concept of Model Being Developed}

The model is a conceptual framework that describes systematic procedures to organize learning experiences to achieve specific learning objectives in the form of series of learning approaches, strategies, methods and techniques. In other words, the learning model is a wrap or frame from the application of learning approach, methods, and techniques. If the learning approaches, strategies, methods, techniques and already elaborate as one comprehensive thing, then this elaboration what we call it learning model.

If it is associated with the development model of Makassarese language learning material as the concept that being developed to produce learning material based on the needs analysis towards elementary school students as the production target. In the learning debelopment model model by Borg and Gall serve as a guide or reference to develop the concept/basic framework of a systematic learning model. In addition, the authors also adopted a model by Brown related to the development phase model of learning materials that are classified into three main phases namely: development, implementation, and evaluation.

\section{Model of Research and Development by Borg and Gall}

Research and Development (R\&D) can be simply defined as the research methods used to produce a particular product and effectiveness test of the product. From this definition, research and development has implications on two main points, namely: 
product and effectiveness. Research and development is defined as a process or steps to develop a new product or improve existing products, that can be accounted. Besides that $\mathrm{R} \& \mathrm{D}$ can also be defined as a process to produce $100 \%$ new and modification event innovative products that exist but have the authenticity, validity and reliability through the process with criteria and scientific standards with repeatedly.

Related to the complexity of the mechanisms and measures of research and development in the field of education Borg and Gall (2003: 542-543) states there are ten steps in an implementation of research and development in the field of education, among others: (1) need analysis, (2) planning, (3) developing a preliminary form of the product, (4) preliminary field testing, (5) revising the main product, (6) playing field testing, (7) operational product revision, (8) operational field testing (9) the final product revision and (1) dissemination and implementation. Ten step is a step that serves as a systematic guidance for researchers to produce a model of the development of learning materials. Such steps need to be carried out in stages in order to obtain maximum results and quality.

Related to the complexity of the research and development mechanisms and measures in the field of education by Borg and Gall (2003: 542-543) states there are ten steps in an implementation of research and development in the field of education, there are: (1) need analysis, (2) planning, (3) developing preliminary form of product, (4) preliminary field testing, (5) revising main product, (6) main field testing, (7) operational product revision, (8) operational field testing, (9) final product revision dan (10) dissemination and implementation. The step mentioned above is a step that serves as a systematic guidance for researchers to produce learning materials from the development model. These steps need to be carried out step by step in order to obtain maximum and best quality in results.

\section{Model by Brown}

Brown (1995: 139-140) suggests the development model of learning materials is a process that involves three main phases, namely: (a) develop instructional materials, (b) learning in the classroom (field testing), and (c) evaluation of instructional materials. The first phase of the development phase consists of activities (a) needs analysis, (b) defining goals and objectives, (c) test the ability of beginning and student characteristics, and (d) preparing instructional materials as a product. Furthermore, the second phase is the implementation phase of learning include (a) teaching and learning in the classroom, (b) a discussion between teacher and author of learning materials, and (c) revision for final repairs, and then the third phase of the evaluation, in this phase includes five case namely: (a) evaluating learning materials, (b) revision of learning materials, (c) generating and designing the learning materials, (d) distribution and publication (internally or externally on a small scale or large), and (e) it should be noted materials teaching never ends at a certain point he is always evolving according to the needs of trends that are highly dependent on the needs of learners at a particular time. 


\section{Position and Function of Makassarese Language}

Makassarese language serves as regional language. This position is based on the fact that the local language into the language of instruction and the connections between speakers of the regional language and culture as well as supporting the community and society generally in South Sulawesi province, spesificly in Makassar city. This can be seen in the depiction of the Makassar people, which is in the tradition of attitudes, and language is what distinguishes it from other public entity. Although in many writings, community groups called Makassar tribes. Nonetheless, broadly in society, both major tribes living in South Sulawesi, the Bugis and Makassar tribes, more commonly incorporated into the Bugis-Makassar. In fact, it is not much of a difference, which is prominent only in the language it uses. Therefore, the designation of Makassar society is more often associated with the speakers of the regional language. (Wahid, 2007: 2728)

According to Alwi and Sugono (2003: 40), the position of the regional language should be viewed from two perspectives: (1) the regional language as communication tool for the speakers who come from the same ethnic group, and (2) the regional language related to Indonesian language. If viewed from the position that mentioned in the first, regional language serves as: (1) the symbol of the pride of the region, (2) the interface in the family and local communities, (3) a means of supporting regional and Indonesian cultures and (4) supporting regional and Indonesian literature. However from the four from five functions mentioned above has not gone as expected.

While from the side of teaching of the regional language, Halim identifies three main functions, namely: (1) communication tool, (2) educational tool, and (3) cultural tool. (Halim, 1985:184) The function of language as communication tool intended for students to speak regional language properly, it contains the local wisdom value and respect or manners. In Makassarese language there is a concept about sipakatau containing the values of respect among the speakers, people who talk, and those who talk about. For example, pronouns honorifiks /-kik/, /-tak/, /-kita/ are used for older people, whereas the friend of the same age use /-ko/ as the sentence from the child to his parent: "Lekbakmakik nganre tata?" (Dad, have you eat?) while with his friend use the sentence "Lekbakmako nganre Baco?" (Baco, have you eat?).

Educative function is directed so that students can acquire the regionak culture values for the purpose of forming the nation personality and identity through the use of the concept "sipakatau" and "sipakainga" which means mutual respect and remind each other. Besides that the educative function can also be developed through literature; as in Makassarese folklore with moral values, and educational values. As exemplified in the story of 'Todorakayya ri tautowana', this story provides a lesson to the children the importance of respect and obedience to parents that in the end we can reap the wisdom that in the realm of regional language and literature there are many local wisdom values that can develop the educative function, namely the function for character building. 
Cultural function directed to excavate and embed the regional culture values as the effort to build the student identity and form the filter to reduce the negative impact from foreign culture. If the function as communication tool and educational tool has been performing well, actually the cultural function will be achieved, because the real cultural function is directly related to both functions. Through communication tool and educational tool are expected to be embedded regional culture values. If the effort to embed the cultural values has been successful, it will awaken a strong cultural identity.

Based on the explanation above, it can be concluded that the position of Makassarese language as the regional language can be viewed from two sides: (1) the regional language as communication tool for the speakers who come from the same ethnic group, and (2) the regional language related to Indonesian language, while the Makassarese language functions can be divided into three main functions: (1) communication tool, (2) educational tool, and (3) cultural tool.

\section{Local Wisdom}

Local wisdom is the view of life, science and life strategies with the form of activities undertaken by the local community to respond various problems in the fulfillment of their needs. In foreign languages often also conceived as local wisdom, local knowledge or local genious.

According Rahyono (2009), local wisdom is human intelligence that is owned by a particular ethnic group that obtained through the community experience. This means that local wisdom is the result of a particular society through their experience and not necessarily experienced by other communities. These values will be attached very strongly to certain communities and the value has been through a long journey time as long as the existence of the community.

From another view, local wisdom can be interpreted as positive values that grow and develop in the community that comes from culture in the past and acculturated with the culture in the present (modern culture), so that it can be implemented on the things that are modern. Although, the people view in general see local wisdom as something old-fashioned or outdated. But with the advancement of education in Indonesia, particularly in the regions. Local wisdom do the transformation into the living values and adapt to modernity.

As described above the local wisdom is positive values that have been passed on from generation to generation. Now it is time the generation of learning material developer to elaborate the local wisdom into the learning material are being developed. In the context of Makassarese language, the local wisdom sources derived from the positive values of Makassar tribes, and widely South Sulawesi society. Local wisdom that represents the Bugis-Makassar tribe, there are: sipakatau (remind each other); sipakalebbi (mutual respect); mali siparappe, rebba sipatokkong (remind each other, appreciate each other, promote each other). Siri 'na pacce value (shy and empathy) is also a local wisdom that inspired the Bugis-Makassar tribe in the daily activity. 
Efforts to do the preservation of local wisdom in the South Sulawesi culture should be followed by strategic steps to provide a bridge of knowledge to younger generations through formal education as a means to understand the local wisdom in the past. One of the strategies to provide an understanding of the aksara lontarak. Aksara lontarak is a traditional script from Bugis-Makassar community. Aksara lontarak generally used to write the rules and regulations of government and society. The emergence of Bugis-Makassar local wisdom is inseparable from the existence of those who preserve aksara lontarak, so that they can use their understanding to explore the local wisdom values that formerly written using the aksara lontarak.

\section{DATA ANALYSIS AND DISCUSSION}

\section{The Development Process of Learning Material}

Before discussing further related to the preservation of local wisdom through aksara lontarak in Makassarese language teaching material in elementary school, it is necessary to understand the steps that have been passed untukl the development process of learning material.

The steps of research and development by Borg and Gall which has been implemented as a pre-stage of the preparation of learning materials development that conduct a preliminary survey in four districts sampled, then determine the four schools in each district are chosen randomly. After a preliminary survey carried out, then continued with a needs analysis and pre-test. These two step is conducted at four schools: SD Inpres Perumnas Antang II (Mangala district), SD Inpres Tello Baru I/2 (Panakkukang district), SD Negeri Gaddong 1 (Bontoala district) and SD 'Aisyiyah Muhammadiyah 03 (Wajo district). From the four schools is further divided into control class and experimental class. Control class is a class that is not given special treatment, while the experimental class (product testing) is a class given special treatment. The results from this steps produce the early stages of Makassarese language learning material product (initial product) contain the form of general purpose and specialpurpose of learning and themes/topics for learning material.

The development process of learning material is focused on activities that support the produce of learning material. The steps that already passed there are: FGD for initial product, product revision, small and large groups for learning material test, experts test, FGD for the product revision, feasibility and readability test, post-test and effectiveness test of learning material. From this process, learning material systematically have additions and improvements according to the inputs of each stage are passed.

\section{The Development of Language Learning Material with Focus on Language Skills}

In the development of learning models to produce learning material, it is necessary to signs that the formulation can be in line with the results of the needs 
analysis that has been done to the teachers, students and principals. Needs analysis is the first step from the series of development of learning model and being reference for the development of learning material that will produce from this research.

The model of language learning with a focus on language skills are not limited to teaching one type of language skills, but also skills that are the focusing on get to emphasized even get the attention and focus, if compared with other skills that are not focusing on. Each part of learning has the objective and goal on the skills that should be mastery.. (Solhan, 2007: 7:20-7:21)

The focus of each language skills: (a) listening, (b) speaking, (c) reading, and (d) writing. Things to note from planning step of learning material development is the basic competencies, learning outcomes, material/content, basic competence language, themes, and interdisciplinary studies integration, and integrated in inter-field of study. (Solhan, 2007: 7:20 to 7:21)

In the development of Makassarese language learning model which is part of the regional language has their own uniqueness. Although, the aspects that should be emphasized is the needs of students, but the characteristic of Makassarese language that is the aksara lontarak should be given special attention as an effort to preserve local wisdom.

\section{Aksara Lontarak in Makassarese Learning Material}

As described in the previous section that the aksara lontarak is a bridge of knowledge for the younger generation to understand and preserve local wisdom. Local wisdom that represent the South Sulawesi culture and Bugis-Makassar tribe is siri' and pacce values. One of the category siri' related to work ethic. In the philosophy of Bugis mentioned:

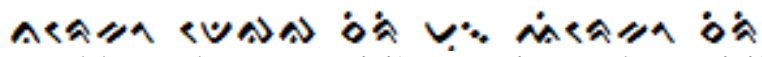

narekko degaga siri' mu, inrengko siri'

If you have no shame then borrow to those who still have a sense of shame (siri')

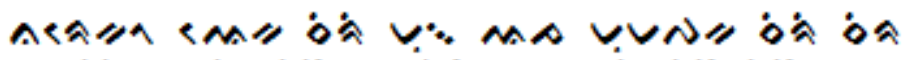

narekko engka 'siri' mu, aja' mumapakasiri'-siri'

If you have no shame then do not embarrass

Furthermore pacce value is the feeling (state ment) solidarity that rises from the heart that can stimulate to action. This value is the ethic (attitude) from Bugis-Makassar people as a moral statement. Pacce directed out of him, while the siri' directed into himself. Siri' and pacce are the direction for the people's behavior in daily life as a driving force in manifesting the patterns of cultural and social systems.

Siri' and pacce values disclosed above is the description that this value is derived through the expressions of the aksara lontarak. Therefore, the development of aksara lontarak in Makassarese language learning material is very relevant. Further in this learning material, aksara lontarak took the places in reading skills on the section of 
new vocabulary, in the other section there is the use of word structure and the main place in the section of aksara lontarak translation. The explanation described as follows:

\begin{tabular}{|c|c|c|}
\hline \multicolumn{3}{|c|}{ Kana Beru (Kosa Kata Baru) } \\
\hline Aksara Lontarak & $\begin{array}{c}\text { Bahasa Makassar } \\
\text { (latin) }\end{array}$ & $\begin{array}{l}\text { Bahasa } \\
\text { Indonesia }\end{array}$ \\
\hline Mレくネヘ & (ammarentah) & memerintah \\
\hline$N A M M A$ & (pa'gaukanna) & peresmiannya \\
\hline NAO & (pa'nassa) & dinobatkan \\
\hline AaAa & (gallarak) & gelar \\
\hline
\end{tabular}

Kana beru (new vocabulary) is supporting component for reading skills. In this section, aksara lontarak stand parallel to Makassarese language (Latin script) and Indonesian language to give students an understanding of the aksara lontarak meaning with Makassarese language latin script and its translation into Indonesian language. Section of this new vocabulary contained in each lesson, thus giving habituation to students

\section{A Penggunaan Struktur Kata}

Kana Kasingarang Anjokjok (Kata Keterangan Sebab)

I lalang basa Mangkasarak niak kana anjokjok sabak, iami antu irawanganna anne:

$$
\begin{aligned}
& \text { " (ka) = sebab } \\
& \wedge a \text { (lanri) = sebab, karena }
\end{aligned}
$$

Contona:

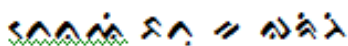

Tenai battu ka garringi

"Tidak datang dia sebab dia sakit"

The use of the word structure also integrate the aksara lontarak in the introduction to the students. Begins with an explanation of the word structure (described in the picture above) is described on kana kasingarang anjokjok (adverb cause), then given the example that begins with aksara lontarak, then explained with Makassarese language latin script and translated into Indonesian language. The structure of this word is also present in every lesson, as a form of habituation to the students.

\section{A Menerjemahkan Aksara Lontarak}

Ukiriki basa Mangkasarak (BM) siagang basa Indonesia (BI) rawanganna anne battu ri aksara lontarakna.

(Tulislah terjemahan bahasa Makassar beserta bahasa Indonesia, kalimat yang berasal dari aksara lontarak dibawah ini)

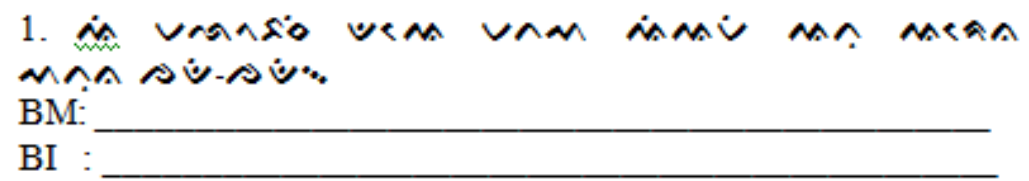


Section of aksara lontarak translation is the part that expose the students ability to understand how to write aksara lontarak. In this section, students are asked to write Makassarese language latin translation, along with Indonesian language from sentences given. Sentences written by students in this section is a synthesis of the reading section that are given on the part being studied.

Based on the above explanation, it can be concluded that the aksara lontarak need to took place in Makassarese language learning material. In this stage of learning material development, aksara lontarak placed in the section of new vocabulary, use of word structure and aksara lontarak translation as an attempt to preserve this aksara through understanding embedded for the younger generation, especiall for elementary school students.

\section{CONCLUSION}

Based on the discussion from the previous sections has been reviewed regarding the preservation efforts of local wisdom through aksara lontarak in Makassarese language learning material for elementary school students. This effort is based on the assumption that local wisdom is a values derived from community life in the past and present that are growing and developing in the midst of community. Then one of the efforts to preserve the values that keep the introductory language when that time they use aksara lontarak.

Expectation with the efforts to conserve aksara lontarak in Makassarese language learning material can be a bridge of knowledge for students to explore local wisdom and apply it in the present conditions. The younger generation, especially elementary school students is the generation that will carry on the struggle of the noble ideals also new ideas and to manifest the glory of the ancestors in the future.

\section{REFERENCES}

Alwi, Hasan dan Dendy Sugono. 2003. Politik Bahasa Nasional. Jakarta: Pusat Bahasa.

Borg, Walter R. dan Meredith Damien Gall. 2003.Educational Research: An Introduction Seventh Edition. Boston: Allyn and Bacon.

Brown, James Dean. 1995. The Elements of Language Curriculum: A Systematic Approach to Program Development. Boston: Heinle\&Heinle Publisher.

Halim, Amran. 1985. Seminar Penulisan Bahan Pengajaran Bahasa. Jakarta: Pusat Bahasa.

Halim H., Abd. 2007. Pengembangan Model Bahan Ajar. Jakarta: Pustaka Press.

Joyce, Bruce, Marsha Weil, dan Emily Calhoun. 2009. Models of Teaching: ModelModel Pengajaran edisi delapan diterjemahkan Achmad Fawaid dan Ateilla Mirza. Yogyakarta: Pustaka Pelajar. 
Mulyana, E. 2003. Kurikulum Berbasis Kompetensi, Konsep, Karakteristik, dan Implementasi. Yogyakarta: Remaja Rosdakarya.

Pribadi, Benny A. 2010. Model Desain Sistem Pembelajaran. Jakarta: Dian Rakyat.

Rabiah, Sitti. 2012. "Model Bahan Ajar Bahasa Makassar sebagai Muatan Lokal: Penelitian dan Pengembangan di Sekolah Dasar kota Makassar". (Disertasi), Universitas Negeri Jakarta.

Rabiah, Sitti. 2013. Pengembangan Materi Ajar Bahasa Makassar berbasis Nilai-Nilai Karakter dan Kearifan Lokal di Sekolah Dasar Kota Makassar. Dipresentasikan dalam Konferensi Internasional Budaya Daerah. Sukoharjo: Ikatan Dosen Budaya Daerah Indonesia. doi: 10.31227/osf.io/s8uv5

Rabiah, Sitti. 2014. "The Learning Model of Makassarese Language Based on the Character Building Concept: Research and Development in Elementary School of Makassar City" (Proceeding of International Seminar on Languages and Arts), Faculty of Languages and Arts, Universitas Negeri Padang. doi: 10.31227/osf.io/en63f

Rahyono, F. X. 2009. Kearifan Budaya dalam Kata. Jakarta: Wedatama Widyasastra.

Solhan, T.W., dkk. 2007. Pendidikan Bahasa Indonesia di Sekolah Dasar. Jakarta: Universitas Terbuka.

Tomlinson, Brian. 2007. Developing Materials for Language Teaching. London: Continuum.

Trianto. 2011. Mendesain Model Pembelajaran Inovatif-Progresif: Konsep, Landasan, dan Implemetasinya pada Kurikulum Tingkat Satuan Pendidikan (KTSP). Jakarta: Kencana, 2011.

Wahid, Sugira. 2007. Manusia Makassar. Makassar: Pustaka Refleksi.

Yurnaldi. 169 Bahasa Daerah Terancam Punah. http://nasional.kompas.com/read/2008/08/11/21544654/169.bahasa.daerah.terancam.pu nah.

\section{ACKNOWLEDGEMENT}

The researcher would like to acknowledge the Directorate General of Higher Education, Ministry of Research, Technology and Higher Education, Indonesia on research funding has been awarded through a Hibah Bersaing scheme in the second year. Hopefully, this study provides a positive contribution to the efforts to develop local languages in Indonesia. 


\section{About the Author}

Sitti Rabiah was born in Makassar. Completing the Bachelor degree (S-1) in Applied Linguistics, Universitas Hasanuddin (1983-1988) and Master degree (S-2) in Indonesian Laguage at Universitas Hasanuddin (1999-2002). Then she continue the Doctoral (S-3) in Language Education, Universitas Negeri Jakarta (2008-2012). Before his completion in doctoral, she get Sandwich-Like Program scholarship from Directorate of Higher Education, Ministry of Education and Culture Republic of Indonesia in collaboration with USINTEC from October 2009 to January 2010 in Ohio State University (OSU), United States of America. She is a lecturer at the Faculty of Letters, Universitas Muslim Indonesia (1993-now) and since October 2013, she served as Head of the Indonesian Language and Literature Studies.

She granted fund from Directorate of Higher Education, Ministry of Education and Culture for her research in Hibah Bersaing scheme for 2 years (2014-2015) entitled The Learning Model of Makassarese Language based on the Character Building (Research and Development in Elementary School of Makassar City) and community service in IbM Kampung Burasa' in Je'nemadinging Village of Gowa Regency for 1 years (2015).

She active in various scientific activities such as: $2^{\text {nd }}$ International Congress of Regional Languages of South Sulawesi II in Makassar, Indonesia (2012), $4^{\text {th }}$ PPSPP International Conference in UKM, Malaysia (2013), 10 ${ }^{\text {th }}$ Indonesian Language Congress (2013) in Jakarta, Indonesia, $3^{\text {rd }}$ International Congress of Regional Culture (2013) in Sukoharjo, Indonesia, National Seminar of Language Education in UNJ, Jakarta, Indonesia (2014), $3^{\text {rd }}$ International Seminar on Languages and Art (ISLA) in UNP, Padang, Indonesia (2014), $36^{\text {th }}$ International Seminar on Scientific Meeting of Indonesian Language and Literature, UAD, Yogyakarta, Indonesia (2014), National Seminar of AJPBSI, Surakarta, Indonesia (2014) and $1^{\text {st }}$ National Seminar of ADOBSI, Surakarta, Indonesia (2015).

She also active in professional organization as member of Masyarakat Lingustik Indonesia (MLI) Chapter Faculty of Letter UMI and member of Asosiasi Dosen Bahasa dan Sastra Indonesia (ADOBSI). In the end, regional language for her is a crutch for the Indonesian national language as well as the identity of the community and should continue to be preserved, one of them through education and research. 